UDC 338.24.021.8(510)

\title{
ANALYSIS OF INTERNAL REGULARITIES OF MODERN REFORMS IN PRC IN THE LIGHT OF SOCIALIZATION PROCESSES
}

\author{
P. Nesenenko \\ $\mathrm{PhD}$ in Economics, Associate Professor, \\ Odessa National Economic University \\ 8, Preobrazhenskaya str., Odesa, 65082, Ukraine \\ nppod@ukr.net \\ O. Artemenko \\ member of the Ukrainian Association of Sinology \\ alarte49@gmail.com
}

Currently, when developing its own successful course of development by certain countries, it is important to study the experience of reforms in modern China. From the end of the 19th century to the present day, the idea of development was formed in it, which later became known as the "theory of modernization". Having come a long way since its inception in Europe, it was combined with the ideas of Chinese politicians and scholars, based on Marxism and the socialist path of development, and gradually turned into Sinicized Marxism as a powerful lever for the renovation of the country.

Unfortunately, these achievements have been poorly studied even in China itself in terms of those internal springs that have provided a powerful upswing for the once underdeveloped country. Analysis of the reforms shows that they are primarily related to the observance and continuity of the theories of K. Marx, V.I. Lenin, Mao Zedong and Deng Xiaoping in search in practice of different approaches to the rise of China's productive forces, which were then improved and actively used throughout the country.

At the same time, the country's success stemmed from the development of socialization forms from the simplest to the most complex ones, where the main strategic role has always belonged to its most important form, i.e. planning. Under these conditions, the market, on the one hand, played a role in raising the productive forces of labor, and on the other regulating the proportions of social production where a large share of living labor was still retained.

Actively using the experience of the Bolsheviks in gaining and maintaining political power, and then the restoration of the war-torn economy, China applied in economic practice the experience of the first regulated market in Soviet Russia, i.e. the NEP. At one time, Marxism, accepted by the Chinese intelligentsia, began to comprehend the country's place in the world and the reforms that took place after Deng Xiaoping came to power. This politician used the logic of formation of socialization forms, and one of them, i.e. the regulated market, capturing its dialectical nature and the need to move away from the dogmatic per-

(C) 2021 P. Nesenenko, O. Artemenko; Published by the A. Yu. Krymskyi Institute of Oriental Studies, NAS of Ukraine and the Ukrainian Association of Sinologists on behalf of The Chinese Studies. This is an Open Access article distributed under the terms of the Creative Commons Attribution License (https://creativecommons.org/licenses/by-nc-nd/4.0/). 
ception of Marx's doctrine, drawing attention to the need to use different economic forms and methods of transformation, involving large mass of people.

Hence, modern Chinese reforms, in fact, proved to be the implementation in practice of a spontaneous dialectical approach to the implementation of problems that combine different forms and means, at first glance far from the traditional economy. In this sense, they correspond to the spirit of our time, i.e. globalization, absorbing all the best that has been achieved in the world, and adapted to the peculiarities of Chinese culture. Globalization has made the world visible, and successful methods of transformation in different countries available for study. Hence, the results of Chinese reforms have long gone beyond this country and allow all states to use them, taking into account their national specifics.

Keywords: economic reforms, Marxism, socialization, plan, planning, transitional economic forms, Sun Yat-sen, Mao Zedong, industrialization, Deng Xiaoping, Sinicized Marxism, modernization, Xi Jinping, Xiaokang, Datong, innovative type of development.

\section{АНАЛІЗ ВНУТРІШНІХ ЗАКОНОМІРНОСТЕЙ ПРОВЕДЕННЯ СУЧАСНИХ РЕФОРМ У КНР У СВІТЛІ ПРОЦЕСІВ СОЦІАЛІЗАЦІЇ}

\section{П. П. Несененко, О. А. Артеменко}

Натепер у разі розробки власного успішного курсу розвитку тими чи іншими державами великого значення набуває вивчення досвіду реформ сучасного Китаю. Починаючи з кінця XIX століття до наших днів у ньому відбувалося формування ідеї розвитку, яка згодом отримала найменування «теорії модернізації». Пройшовши досить тривалий шлях від іiі зародження в Свропі, вона поєдналася з ідеями китайських політичних діячів та вчених, спираючись на марксизм та соціалістичний шлях розвитку, і поступово перетворилася на китаїзований марксизм як потужний важіль поновлення країни.

На жаль, ці досягнення виявилися маловивченими навіть у самому Китаї з точки зору тих внутрішніх пружин, що забезпечили потужне піднесення колись слаборозвиненої країни. Аналіз реформ показує, що вони, перш за все, пов'язані $з$ дотриманням і наступністю теорій К. Маркса, В.І. Леніна, Мао Цзедуна і Ден Сяопіна в пошуках на практиці різних підходів для підйому продуктивних сил Китаю, які потім удосконалювалися і активно використовувалися по всій країні.

При цьому успіхи країни випливали з розвитку форм соціалізації від найпростіших до найскладніших, де головна стратегічна роль завжди належала найважливішій його формі - плануванню та пов'язаними з ним процесами планомірності, що зароджувалась. У цих умовах ринок, з одного боку, виконував роль 3 підйому продуктивних сил праці, а з іншого - регулювання пропорцій громадського виробництва там, де ще зберігалася велика частка живої праці.

Активно використавши досвід більшовиків щодо завоювання та збереження політичної влади, а потім і відновлення зруйнованого війною народного господарства, Китай застосував у практиці господарювання досвід першого регульованого ринку Радянської Росії - НЕП. Свого часу сприйнятий інтелігенцією Китаю марксизм започаткував осмислення місця країни у світі і тих реформ, які відбулися після приходу до влади Ден Сяопіна. Останній використав логіку становлення форм соціалізації і одну 3 них - регульований ринок, вловивши його діалектичний характер і необхідність відходу від догматичного сприйняття вчення К. Маркса, звернувши увагу на необхідність використання різних економічних форм та методів перетворень із широким залученням народних мас.

Звідси сучасні китайські реформи, по суті, виявилися здійсненням на практиці стихійного діалектичного підходу до реалізації проблем, що поєднують різні форми 
і засоби, на перший погляд, далекі від традиційної економіки. У цьому сенсі вони відповідають духу нашого часу - глобалізації, вбираючи у себе все найкраще, що напрацьоване у світі та підігнане під особливості китайської культури. Глобалізація зробила світ видимим, а успішні методи перетворень у різних країнах доступними для вивчення. Звідси отримані результати китайських реформ давно вийшли за межі цієї країни і дають змогу всім державам використовувати їх у себе з урахуванням їхньої національної специфіки.

Ключові слова: економічні реформи, марксизм, соціалізація, план, планування, перехідні економічні форми, Сунь Ятсен, Мао Цзедун, індустріалізація, Ден Сяопін, китаїзований марксизм, модернізація, Сі Цзіньпін, сяокан, датун, інноваційний тип розвитку.

Осмислення досвіду реформ сучасного Китаю має для України велике значення, а те, що розроблялося китайськими лідерами з ініціативи Ден Сяопіна і його сподвижників, починаючи з III пленуму ЦК КПК одинадцятого скликання, що відбувався 18-22 грудня 1978 року, згідно з яким була оголошена нова політика «реформ і відкритості», стало у КНР початком тонкого мистецтва досягнення поставлених цілей. 3 цього періоду в економічну теорію та політику були внесені певні корективи у разі збереження стратегії курсу на соціалізм з використанням магістрального складника - політики модернізації.

Звідси розуміння китайського економічного прориву другої половини XX століття неможливе без його прив'язки до проблем саме модернізації, розкриття суті їі витоків, а потім і специфіки прийняття Китаєм, спочатку 3 урахуванням умов появи низки перетворень Мао Цзедуна, проведення подальших радикальних динамічних господарських реформ Ден Сяопіном, а потім і його послідовниками, починаючи від Цзян Цземіня, Ху Цзіньтао до Сі Цзіньпіна.

Розвитку теорії модернізації сприяли західні соціологи ще у середині ХХ ст., що було пов'язано з розвалом колоніальної системи, посиленням протиріч двох суспільних систем та розвинених і нерозвинених держав, хоча їі підвалини були закладені ще О. Контом, Г. Спенсером, К. Марксом, М. Вебером, Е. Дюркгеймом та іншими видатними вченими. Генеза модерну спочатку збігалася з епохою індустріального суспільства, тісно пов'язаною з теорією ринку або економікою. Після остаточного підриву механізму саморегулювання вартості в період Великої депресії 1929-1933 років, особливо після Другої світової війни, ситуація кардинально змінилася. В концепції модерну, як сучасного етапу історії, почали відбуватися суттєві зміни.

Очевидними стали і суперечності у самій теорії модернізації. Так, вона не могла пояснити не тільки відмінність Західної цивілізації від Східної, але і зміни на стадії постіндустріального суспільстві самого Заходу. Цим, виходячи $з$ теорії К. Маркса, відбувся перехід від головної до цього продуктивної сили праці до науки і культури, з якими економічні чинники у соціумі переставали «працювати». Це викликало потребу в пошуках нових підходів у вивченні сучасних процесів, а з ними і об'єктивну зміну уваги соціологів від дослідження економіки або ринку до культури. Причому не останню за значенням у цьому процесі. 
У 80-ті роки ХХ ст. у зв'язку з появою постмодернізму в теорії модернізації відбулась ії відмова від універсалізму та конфронтаційності, а $з$ ними зникло і протиріччя між марксизмом і згаданою теорією. Більш того, наприкінці 90-х років стало очевидно, що поняття модернізації відображає особливий вид розвитку, де відсутні різко окреслені періоди між революційним та еволюційним етапами, коли один плавно переходить в інший [Виноградов 2010, 104-105].

У цей період західні економісти продовжували поглиблювати питання господарської практики шляхом аналізу відносин сил попиту та пропозиції, віддаляючись від прогностичних функцій економічної науки та проблем еволюції суспільств, віддавши це питання на відкуп соціологам.

Причина подібного стану західної класики, на наш погляд, переважно полягала у пануванні головним чином аналітичного методу. Він полягав у тому, що спочатку охоплювались найголовніші риси цілого у першому наближенні (метод апперцепції), а потім відбувалось послідовне дослідження його частин у тісній прив'язці до виявлених раніше закономірностей цілого.

Така багатогранність аналізу, в якому скрупульозно враховувались усі аспекти дійсності, стосовно певного часу, добре слугувала суто практичній меті - пошуку нових сторін покращення ведення господарської практики. Виникала прекрасна фотографія дійсності, але без аналізу причин та форм постійних змін у ній [Артеменко 2018].

Іншими словами, втрачалось уявлення стосовно вектора змін цілого і його частин, котрі постійно перебували у русі як кадри уповільненого фільму. То ж не дивно, що західна економічна наука, маючи у своєму розпорядженні детально відпрацьовану для потреб підприємництва неокласичну теорію А. Маршалла [Маршалл 1993], довго не могла збагнути причину кардинальної зміни дійсності, що відбулася з настанням Великої депресії 1929-1933 років.

Більш того, намагання після чотирьох років кризи відновити дію вільного ринку, який пішов в історію, виявилися марними. Звідси, наприклад, президент США Ф.Д. Рузвельт та підприємець Г. Форд вимушені були самі почати навпомацки шукати вихід зі становища, що склалось, так до кінця і не розуміючи причини внутрішніх грунтовних змін у соціумі, що відбулись, своїми діями, напівсвідомо, розвиваючи процеси соціалізації у суспільстві.

Не вдалось це повною мірою зробити і Дж.М. Кейнсу, теорія якого, на відміну від його вчителя А. Маршалла, мала яскраво виражений функціональний характер [Кейнс 1978]. Потім частково цей недолік спробував усунути видатний польський вчений-економіст М. Калецьки, побачивши у загальній кризі розвинутих країн суттєві зміни соціального характеру, і скориставшись теорією К. Маркса в нових умовах першої третини XX ст., через дослідження змін класової структури суспільства, показав, у чому коріняться причини цього явища [Несененко, Артеменко, Патлатой 2019, 144-148].

Що стосується сучасного стану економічних процесів, то у них і досі відсутній глибокий політико-економічний аналіз. Тому теорія модернізації і досі має яскраво виражене соціологічне забарвлення, де розчинилась найважливіша сторона сучасної дійсності - процеси соціалізації з грунтовним аналізом багатогранних економічних форм підриву вартісних процесів саморегулювання і їх діалектичного зняття як основи - капіталу. 
Виникла унікальна ситуація, коли соціологи, а не економісти, відійшовши від економічного пояснення дійсності і зробивши акцент на культуру, вперше змогли підійти до пояснення специфіки нового суспільства та його змін у русі, спочатку від традиційного стану до індустріального, а потім і постіндустріального, чим, нарешті, пролили світло не тільки на сучасні суспільства Заходу, але і Сходу. Правда, поки що з боку соціології, використавши в ній новий модернізаційний підхід, на відміну від формаційного і ичивілізащиійного, що застосовувалися до цього.

Подібний метод для опису сучасних змін у країні отримав широке використання і у Китаї з другої половини ХХ століття. Маючи у своєму розпорядженні не досить глибоко розроблений політекономічний науковий складник, керівництво країни, виходячи із теорії модернізації, почало крок за кроком відпрацьовувати зміни у суспільній надбудові країни, використовуючи для цього концепцію західного модерну, чим, власне, поклали початок генерування широкого простору розвитку продуктивних сил.

Спочатку Китай, намагаючись вирватись із феодального стану і досягти рівня розвинених сучасних суспільств, на початку XX ст. взяв за основу західні концепції розвитку, виходячи із національної специфіки країни. Сунь Ятсен, один із найвизначніших політичних лідерів країни, саме тоді усвідомив і сформулював для країни необхідність радикальних змін суспільного устрою та запозичення нових методів управління і інтелектуальних стандартів. Виходячи 3 цього, ним були висунуті два магістральні завдання: гонитва за світовим лідером та зміна ладу з примусовою (шляхом революції) ліквідацією старих та утворення нових інститутів, замість поступових змін поглядів імператора та його чиновників на нові [Виноградов 2010, 109].

Пізніше, чітко дотримуючись принципу наступності, як одного із найважливіших факторів розвитку Китаю, Мао Цзедун продовжив цю лінію, провівши кардинальні революційні зміни у суспільстві. Так, 1 жовтня 1949 року за його активної діяльності була утворена КНР, а потім шляхом індустріалізації проведена побудова матеріально-технічної бази соціалізму. Пізніше, намагаючись вирішити питання підйому економіки, Китай приступив до реалізації ідеї «великого стрибка» зі збільшення на селі виробництва металу, а потім і розгортання в країні Культурної революції, що мала на меті ліквідувати вплив конфуціанства і відсторонити старі кадри від управління країною. Саме збереження залишків старого мислення цих людей Мао Цзедун вважав головною причиною провалу його реформ [Мао Цзедун 1949-1953].

Одночасно ним були розвинуті положення політики модернізації стосовно трьох ії ключових складників, як-то: реалістичного і прагматичного підходу до справи; вироблення власного незалежного і самостійного політичного курсу Китаю та використання в національній економіці спрощених форм і методів модернізації, зрозумілих кожному пересічному жителю Піднебесної.

Однак проведення індустріалізації за сталінським зразком заклало в продуктивні сили суспільства проблеми, які поряд з наступним впровадженням суто китайських витворів - політики «великого стрибка» та Культурної революції - призвели до загострення в країні протиріч та гальмування можливостей досягнення високих темпів її розвитку. Саме на причини цього вказав один з найвидатніших економістів-теоретиків Китаю Сунь 
Ефан, назвавши два «кореня зла» традиційної теорії соціалізму - iдеалізм і метафізику.

Перше зло, на його думку, - волюнтаризм, внаслідок чого всі економічні питання пояснювались причинами, що виводились із політики та ідеології та 3 власної волі суб' єкта, чим ігнорувалась дія об'єктивних економічних законів.

Друге зло - метафізика, що тлумачила соціалістичну економіку як натуральне господарство з відсутніми у ньому ринку, вартості, ціни, абстрактної праці тощо, де не бралась до уваги економічна ефективність виробництва, а 3 нею співвідношення прибутків та збитків.

На доповнення сказаного можна додати, що проблема, яку порушив Сунь Ефан, полягала у збереженні на той час у Китаї значних напластувань натурального способу виробництва, який отримав нові грані, внаслідок насаджування іiі керівництвом централізованої системи планування. На перший погляд, це виглядало як слідування положенню К. Маркса про фундаментальну рису комуністичного виробництва - його планомірний характер.

Однак тут мав місце один нюанс. Планування, про яке писав К. Маркс, мало у своїй основі «Устрій громадського життєвого процесу ... який стане продуктом вільного суспільного союзу людей і буде перебувати під їх свідомим планомірним контролем. Але для цього необхідна певна матеріальна основа суспільства або ряд певних матеріальних умов існування, які являють собою природно вирослий продукт довгого і болісного (курсив авторів) процесу розвитку» [Маркс 1960, 90].

Тому після зміни суспільного ладу план та його сутність -планомірність у своїй розвиненій формі зразу ж виникнути не могли. Більш того, планомірність могла з'явитися тільки з розвитком крупного машинного виробництва і процесів безперервності та паралельності виробництва як ланцюжків технологічних процесів [Лыков 1984, 20-21], яких на той час у Китаї, враховуючи його перебування ще у феодальній ері, не могло бути. Іншими словами, досліджуючи будь-яку країну в площині проблем її постринкового господарювання та форм, в яких вони діють, треба розрізняти план, планування та планомірність. Причому перші дві категорії є формами планомірності, як їх сутності або змісту. Більш того, план та планування можуть існувати без наявності планомірності.

Звідси, відзначаючи в Китаї процеси індустріалізації та отримані результати $з$ їх завершення, можна констатувати - керівництво країни фактично виходило із наявності розвиненої планомірності, якої тоді не було, а тому без розвитку ринку планування мало тільки локальний характер і не охоплювало масовидну кількість процесів господарювання. Там же, де цей зв'язок міг існувати як всеохоплюючий, правда, у менш розвиненій формі, його міг дати тільки ринок, а через кооперацію і ії розвиток можливість цим зв'язкам дорости до форми машинного виробництва, що невідтворно утворювали уже згадані технологічні ланцюжки, як основу планомірності, більш високого рівня загальних, а не локальних відносин, яких ще не було в умовах натурального господарства. Іншими словами, розвиток ринку давав можливість створити всеохоплюючі зв'язки, а його рух до капіталу і машинного виробництва, як його продуктивних сил, трансформувати у планомірні взаємини спочатку як технологічні, а потім і соціальні. 
Збереження ж централізованого планування не дозволяє створити чітко працюючу систему, яка б оперативно реагувала на зміни у виробництві і споживанні, що об'єктивно викликає появу постійних диспропорцій між ними, уникнути яких можна тільки розвиваючи планування 3 використанням для цього ринку у формі індикативного плану. Іншими словами, потрібен регульований ринок. А це категорія, що відображає перехідний стан від економіки до загального планування на основі його розвинених форм, що спирається на планомірність. До речі, Японія, проаналізувавши дискусії радянських економістів 30-х років XX століття стосовно перспектив впровадження індикативного та директивного планування в СРСР, дійшла висновку, що для підйому країни потрібно брати перший варіант. Результатом його використання стало всім добре відоме «японське диво».

Регульований ринок - це одна із тих перехідних економічних форм, про яку в Китаї тоді ще мало хто розумів. Тому з певного часу у дію вступила практика знаходження найбільш вдалих форм ринкового господарювання, а потім їх селекція та поширення у наступних планах розвитку країни. Таким чином, ринок і план виявились поєднаними.

3 теоретичного боку зрозуміти, чому це працює, стає можливим, якщо розглядати їх як перехідну форму від ринку до плану, тобто як регульований ринок. Помилка радянського керівництва сталінського періоду після згортання ленінського НЕПу полягала у тому, що воно спробувало використати переваги планування в його розвинутій формі за відсутності зрілої планомірності, і виходячи 3 цього будувати соціалізм. Цим ігнорувалась значна тривалість цих процесів у часі, про які попереджав К. Маркс, як перехід від ринку до розвиненого плану - планомірності. Що стосується радянської Росії, як і Китаю, то це положення ускладнювалося ще й наявністю значних нашарувань доринкових форм, які потребували діалектичного зняття в найкоротший термін.

Сказане аж ніяк не означає неможливість застосування планування, або тільки негативні його сторони, у разі відсутності або нерозвинутості планомірності. Централізоване планування, а воно було тоді головним, дозволяло виконати два стратегічні завдання: по-перше, централізувати ресурси на вирішальних напрямах, чим забезпечити мобілізаційний розвиток економіки. Згадаймо, наприклад, індустріалізацію у СРСР наприкінці 20-х - початку 30-х років XX століття. I по-друге, створити потужний соціальний ліфт просування на керівні посади найбільш талановитих та обдарованих людей, що в поєднанні з прекрасною радянською освітою, взятою з прусської системи, дало потужний поштовх виходу СРСР на рубежі передових країн. До речі, Китай широко використовував подібні ліфти ще зі стародавніх часів, на відміну, наприклад, від Індії, де на заваді була кастова система. Звідси, як результат, великі та всім добре відомі відкриття, зроблені у Китаї у ті часи, - порох, паперові гроші, компас тощо.

Мао Цзедун, спираючись на дематеріалізацію і натуралізм (терміни Сунь Ефана), як форми метафізики, значно перебільшив можливості досягнутого на той час ступеня усуспільнення, що мало наслідком гальмування розвитку ринкових процесів, а з ними катастрофічне падіння матеріальної зацікавленості людей у результатах своєї праці, наслідком чого неминуче ставали низькі темпи зростання виробництва. 
Дуже швидко з'ясувалось, що планування в масштабі всього суспільства без розвитку ринку, а через нього кооперації у формі крупного машинного виробництва, як результату його розвитку, не дозволяє прийти до безперервності і паралельності виробництва, а з ними і планомірності. Впровадження ж централізованого планування, навпаки, посилювало процеси натуралізації господарства, позаяк регулювання суспільних пропорцій йшло згори від міністерств, відомств, що заміняло собою ринок, заганяючи його в тінь.

3 моменту смерті Мао Цзедуна все більш очевидно стали проявлятися хиби централізованого планування, що зводили нанівець одну із його сильних сторін - мобілізаційну складову частину. Вона широко використовувалась як головний інструмент політики «воєнного комунізму» за часів громадянської війни, що спочатку використали більшовики, а потім свого часу і китайці. Вона дала прекрасний результат, тому Китай продовжив ії впроваджувати на початку формування нового суспільства, але їх аж ніяк не можна вважати методами побудови соціалізму, як стверджують деякі автори, а специфічними форс-мажорними обставинами, викликаними, наприклад, війнами з необхідними у таких умовах жорсткими формами централізації ресурсів для перемоги над ворогом, де ринок працювати не може, а необхідна жорстка централізована система розподілу, що функціонує за законами натурального господарства, в якій встановляється зрівняльний розподіл виробленого, і де повинен об'єктивно панувати директивний план. Звідси у воєнних обставинах централізовані системи, побудовані на принципах натурального господарства, завжди мають незаперечні переваги над ринковими. Правда, принципи мобілізаційності, у разі вмонтування в неї еволюційної сторони розвитку, пізніше дозволили зняти негативні явища як в економіці, так і суспільстві та значно посилити можливості планування.

Однак з огляду на те, що Китай спочатку взяв на озброєння досвід сталінського СРСР [Сталин 1952], починаючи з 1949 року, тобто створення КНР, недоліки директивної системи планування поступово ставали все більш очевидні. Потрібні були кардинальні зміни. I вони не забарилися. За вирішення проблем, що накопичились за десятиріччя і особливо заглибились після Культурної революції 1967-1977 рр., взявся Ден Сяопін.

Починаючи з грудня 1978 року, висунувши новий курс, він зберіг та активно розвинув положення попередників, взявши за основу напрацьовану ще у 1950-х роках главою Держради КНР Чжоу Еньлаєм та прийняту у 1963 році як офіційну політику Китаю, нову доктрину розвитку країни, правда, згорнуту 3 початком Культурної революції. Ден Сяопін поклав ці положення в основу перетворень як стрижневі аспекти модернізації, якими стали Політика реформ і відкритості та концепція чотирьох модернізацій - промисловості, сільського господарства, національної оборони, науки і техніки [Дэн Сяопин 1997].

Головна проблема, що повстала перед реформатором, полягала у необхідності швидкого і значного зростання продуктивності праці як головної умови перемоги будь-якого суспільного ладу. Звідси почався пошук шляхів того, як це зробити. Історія розвитку успішних країн показала, що цим інструментом $\epsilon$ ринок. Однак Ден Сяопін бачив і можливі негативні наслідки цього процесу - швидку появу з посиленням дії ринкових сил і генези капіталізму, його носіїв - буржуазії, з послідуючим захопленням нею і влади, що не входило у плани китайського керівництва. 
Тому вибравши курс створення умов розвитку соціалізму, спочатку потрібно було забезпечити зростання добробуту всіх верств населення (голодні люди і соціалізм - непоєднувані явища, говорив Ден Сяопін), одночасно зацікавивши кожного із пересічних громадян Китаю у новому курсі, відвертаючи загрозу появи капіталізму. Однак рух до соціалізму був неможливий без впровадження нових технологій, яких Китай тоді ще не мав, що породило необхідність розробки другої сторони китайського марксизму - відкритості зовнішньому ринку.

Одночасно в Китаї відбулась відмова від монополії загальнонародної власності на засоби виробництва як обов 'язковий початок руху до соиіалізму, що було закономірним явищем. Адже вона може виникнути тільки за умови, коли загальна праия як праця всіх стане у більшості ще й науковою діяльністю. Звідси відомий вислів К. Маркса стосовно того, що пролетарі повинні знищити працю, коли вона, втрачаючи риси праці, поступово буде трансформуватися на діяльність з гармонійного розвитку людини, де неминуче виникне розподіл по потребах, а конкуренція зміститься зі сфери обігу у виробництво. Іншими словами, рух до загальнонародної власності на засоби виробництва піде через діалектичне зняття приватної власності, яка на початкових етапах розвитку соціалізму, де є значні напластування доринкових форм, буде певний час зберігати риси особистої власності, яку спочатку треба трансформувати на приватну, а потім і суспільну [Мартыновский 2008, 40].

Одночасно перед Китаєм постало питання і про зростання продуктивності праці у середині країни там, де значною мірою зберігалася ручна праця. Це перш за все аграрний сектор, що мав забезпечити зростання виробництва сировини для промисловості та продуктів харчування населенню великої країни. Потрібно було стимулювати індивідуальну ініціативу селян, яку міг розбудити тільки повноцінний ринок. Почались експерименти з пошуку нових форм стимулювання праці на місцях. У селах цим стало введення сімейної підрядної системи відповідальності, поряд з реформуванням сфери обігу села iз заохоченням різноманітних форм торгівлі, з розвитком найманої праці тощо. Одночасно розвивались організаційні форми кооперування селян на зразок ленінського НЕПу, від простих форм до виробничих, ліквідованих у СРСР сталінською індустріалізацією [Ленин 1970]. До речі, Японія під час реформування власної аграрної сфери свого часу активно використовувала ключові ідеї роботи В.І. Леніна «Про кооперацію».

Таким чином, усе, що стимулювало зростання продуктивності праці, було задіяне. Це неважко побачити, аналізуючи послідуючі доповнення в доктрину модернізації. Однією із таких, виходячи із завдань певного часу, стала ідея «потрійного представництва» третього покоління керівників на чолі з Генеральним секретарем ЦК КПК Цзян Цземінем і «наукова концепція розвитку» четвертого покоління, представлена генеральним секретарем Ху Цзіньтао, що внесли доповнення в надбудову суспільства і уточнили ідею модернізації, відкривши новий простір розвитку продуктивних сил.

Правда, на відміну від попередніх теоретичних напрацювань, вони не мали такого поглибленого характеру, як напрацювання Ден Сяопіна. Так, ідея «потрійного представництва» включила у структуру суспільства як іiі структурного представника інтелігенцію, що суттєво піднімало іiі в політичних правах. 
Одночасно була відкрита дорога в партію приватним підприємцям і навіть представникам великого бізнесу. В результаті діяльність цих груп отримала могутній поштовх у розвитку продуктивних сил країни.

Таким чином, вирішувалось питання головного протиріччя, що пройшло ряд етапів від протиріччя між зростаючими матеріальними і духовними потребами народу і відсталими продуктивними силами На XII з'їзді КПК, що відбувся у вересні 1982 року, у доповіді тодішнього Генерального секретаря ЦК КПК Ху Яобана метою соціалістичного будівництва проголошувалося «задоволення постійно зростаючих матеріальних і культурних потреб народу», а у доповіді генсека Чжао Цзияна на XIII з'їзді КПК (жовтень-листопад 1987 року) зазначалось: «Головне протиріччя, яке постає перед нами на нинішній стадії, - це протиріччя між зростаючими матеріально-культурними потребами народу і відсталим суспільним виробництвом» [Виноградов, Салицкий 2019, 175].

На XIX з'їді КПК у жовтні 2017 року Сі Цзіньпіном було проголошено нове головне протиріччя - між постійно зростаючими потребами народу на краще життя і нерівномірністю і неповнотою розвитку. Більш того, до цього було додане цікаве доповнення про те, що «Піднебесна належить усім» [Виноградов, Салицкий 2019, 175], що недвозначно вказувало на можливість встановлення однакових стартових умов для розвитку кожної людини незалежно від ії достатку.

Відмічений ряд протиріч, викладених вище, вказує на наявність на початковому етапі руху Китаю до соціалізму протиріччя на рівні вирішення проблем, перш за все, матеріального характеру, як підняття добробуту людей. Саме це свідчить про те, що праця в Китаї ще залишається головною продуктивною силою суспільства.

Таким чином, з вище викладеного матеріалу можна зробити низку висновків, що демонструють витоки низки грубих помилок, які призводять до абсурдних висновків, пов'язаних з ігноруванням перехідних форм, їх суті та логіки розвитку, як стосовно специфіки окремих країн, так і спроби показати те, що марксизм не може бути практичною настановою побудови соціалізму.

Зауважимо, що останнє положення певною мірою точне. Так, К. Маркс у разі створення політичної економії як анатомії суспільства не писав посібник для господарюючого суб'єкта. Завдання було іншим - показати логіку розвитку капіталізму, конкретні форми підриву його основ - вартісних процесів господарювання і об'єктивність появи того класу, який буде його могильником. Тому головним практичним результатом його вчення стало обгрунтування появи наукового соціалізму [Артеменко 2018].

При цьому К. Маркс ввів в аналіз низку спрощень, що робить неможливим використання його теорії для безпосередньої практики, за виключенням хіба що вчення про суспільне відтворення. Тому, маючи перед собою стратегію розвитку, важливо її наповнювати конкретними формами господарської практики, які добре відпрацьовані в західній економічній думці у вигляді науки економіки, що, до речі, і робить сучасне китайське керівництво, коли йдеться про конкретні форми досягнення певного господарського або суспільного результату. 
Однак з огляду на швидкі зміни в дійсності, практика все більше буде потребувати глибокого розуміння об'єктивної логіки цих змін, тобто стратегії розвитку, яку і дає марксизм через свій діалектичний метод дослідження. Звідси марксизм у Китаї із класової теорії давно став державною ідеологією, що характерна для слаборозвинених країн.

На початку другого десятиліття ХХІ століття склалася потреба у великому доктринальному оновленні курсу КПК. Цією роботою зайнялося п'яте покоління китайських керівників на чолі з Сі Цзіньпіном, який звернув увагу на необхідність відпрацювання нової політичної системи і принципів побудови КПК, відповідно до неї, для відтворення більш ефективних форм функціонування партійного апарату, а з ним і суспільства [Си Цзиньпин 2014].

У дослідженні методів, що використовувалися керівниками Китаю в пошуках шляхів швидкого підйому економіки країни, неважко побачити вплив праць К. Маркса та В.I. Леніна, на що недвозначно було вказано у період п’ятого етапу розвитку країни (з 2002 р. - по сьогодення), що полягає у втіленні ідеології «трьох представників», яка поєднує у собі ідеї марксизму-ленінізму, вчення Мао Цзедуна і Ден Сяопіна [Селищев, Селищев, 121-129], та була підтверджена на XIX з'їзді КПК у 2017 році. Як окремий етап він почався 3 проведення реформ Ден Сяопіном, а потім був підхоплений його послідовниками та Сі Цзіньпіном.

Нова мобілізаційна модель розвитку Китаю спочатку будувалася на основі централізованого планування, що дозволило вперше повною мірою побачити, оцінити та використати переваги мобілізаційного типу розвитку, який надалі отримав істотне посилення.

Показово, що кожен новий етап розвитку Китаю завжди мав на меті формування нової ідентичності країни, викликаючи необхідність розробки цілої низки заходів з його досягнення. 3 початком реформ Ден Сяопіна 31978 року i їх продовження [Дэн Сяопин 1997] до 2021 року головним завданням керівництва країни було забезпечення всіх жителів Китаю елементарними засобами життєдіяльності, наприклад, основними продуктами харчування, одягом і житлом, зафіксованому як побудова суспільства «середнього достатку» - «сяокан». Зараз поставлене завдання набагато ширше і складніше. Розпочатий 3 2021 по 2049 роки новий етап модернізації, відомий як побудова нового ідеального суспільства «великої гармонії» - «датун», повинен вивести країну на якісно новий рівень.

Так, до 2050 року ставиться завдання знаходження нової ідентичності Китаю. Можна прогнозувати, що це буде набувати форми все більшого руху 3 переходу від централізованого планування до індикативного. А це дозволяє вийти на принципово новий рівень розвитку країни, перетворивши одноразовий акт підведення соціального організму, що реформується до певних критеріїв з ручного режиму, як це було з початку реформ, на автоматичний. Причому останній досягається за допомогою тієї ж мобілізаційної моделі розвитку, правда, в основі якої заздалегідь усе більше буде закладатися, як магістральний елемент руху, інноваційний тип.

Як результат, з'являються і розвиваються різновиди планування як однієї із головних форм соціалізації, що йде від локального до державного, розрахованого від п'яти років і до десятиліть, як стратегічне планування, як способу 
появи та реалізації планомірності. Одночасно йде бурхливий розвиток нових технологій як форми появи та посилення нового зв'язку не по минулій праці (вартості), як в умовах ринку, а живій (планомірності) з наукою і культурою, як їх підгрунтям, що $є$ формами соціалізації як антиподу ринку та капіталізму. Звідси Китай розвиває різноманітні форми соціалізації як стратегічні засади своєї могутності, де ринок відіграє роль інструменту стимулювання продуктивності праці та перехідної форми з корегування суспільних пропорцій там, де ручна праця ще посідає значне місце.

\section{ЛІТЕРАТУРА}

Артеменко О.А. До питання про класичну та марксистську політичну економію. Економічна спадщина К. Маркса: погляд через призму століть : збірка матеріалів Всеукраїнського круглого столу, 25 квітня 2018 року. Київ : КНЕУ, 2018. C. 221-224.

Виноградов А.В. Китайская модернизация в сравнительной перспективе сравнительный анализ процессов модернизации. Сравнительная политика. 2010. № 1. C. 104-120.

Виноградов А.В., Салицкий А.И. Можно ли говорить о формировании в Китае нового общественного строя? Вестник Российской академии наук. 2019. Том 89, № 2. C. 172-178.

Дэн Сяопин. Строительство социализма с китайской спецификой. Москва : Наука, 1997. 364 с.

Кейнс Дж. М. Общая теория занятости, процента и денег / пер с англ. Под. ред. А.Г. Милейковского, И.М. Осадчей. Москва : Прогресс, 1978. 494 с.

Кіктенко В.О., Гончарук А.З., Гобова Є.В. 40 років Політики реформ і відкритості Китаю. Вісник Наџіональної академії наук Украӥни. 2019. № 4. C. $68-82$.

Ленин В.И. О продовольственном налоге (Значение новойполитики и её условия). Полн. собр. соч. изд. 5-е. Т. 43. С. 205-245.

Мао Цзедун. Избранные произведения: в 4-х т. Москва : Изд-во иностранной литературы, 1949-1953.

Маркс К. Капитал / Маркс К., Энгельс Ф. Соч. 2-е изд. Т. І. Т. 23. С. 43-784.

Мартыновский С.В. Экономическая политика: проблемы достижения цели. Одесса : Пальмира, 2008. 186 с.

Маршалл А. Принципы экономической науки: в 3 т. Москва : Прогресс : Универс, 1993.

Методические указания по спецкурсу «Проблемы товарно-денежных отношений при социализме» для студентов III курса заочного отделения всех форм обучения / Сост. К.В. Лыков. Одесса : ОИНХ, 1984. 32 с.

Несененко П.П., Артеменко О.А., Патлатой О.С. Теоретичні основи економічної політики : навчальний посібник. Київ : ФОП Гуляєва В.М., 2019. 306 с.

Селищев А.С., Селищев Н.А. Китайская экономика в XXI веке. СанктПетербург : Питер, 2004. 240 с.

Си Цзиньпин. О государственном управлении. Пекин : Издательство литературы на иностранных языках, 2014. 630 с.

Сталин И.В. Экономические проблемы социализма в СССР. Москва : Госполитиздат, 1952.96 с. 


\section{REFERENCES}

Artemenko O.A. (2018), Do pitannya pro klasichnu ta marksists'ku politichnu ekonomiyu. Ekonomichna spadshchina K. Marksa: poglyad cherez prizmu stolit': Zb. materialiv Vseukr. kruglogo stolu, 25 kvitnya 2018 roku. Kyiv: KNEU, 2018. S. 221-224. (In Ukrainian).

Vinogradov A.V. (2010), Kitaiskaya modernizatsiya v sravnitel'noi perspektive sravnitel'nyi analiz protsessov modernizatsii. Sravnitel'naya politika. 2010. No. 1. S. 104-120. (In Russian).

Vinogradov A.V., Salitskii A.I. (2019), Mozhno li govorit' o formirovanii v Kitae novogo obshchestvennogo stroya? Vestnik Rossiiskoi akademii nauk. 2019. tom 89, No. 2. S. 172-178. (In Russian).

Den Syaopin. (1997), Stroitel'stvo sotsializma s kitaiskoi spetsifikoi. Moskva : Nauka, 1997. 364 s. (In Russian).

Keins Dzh. M. (1978), Obshchaya teoriya zanyatosti, protsenta i deneg / per s angl.; Pod. red. A.G. Mileikovskogo, I.M. Osadchei. Moskva: Progress, 1978. 494 s. (In Russian).

Kiktenko V.O., Goncharuk A.Z., Gobova E.V. (2019), 40 rokiv Politiki reform i vidkritosti Kitayu. Visnik Natsional'noï akademï nauk Ukraini. 2019. No. 4. S. 68-82. (In Ukrainian).

Lenin V.I. (1970), O prodovol'stvennom naloge (Znachenie novoipolitiki i ee usloviya). Poln. sobr. soch. Izd. 5-e. T. 43. S. 205-245. (In Russian).

Mao Tszedun. (1949-1953), Izbrannye proizvedeniya: v 4-kh t. Moskva: Izd-vo inostrannoi literatury. (In Russian).

Marks K. (1960), Kapital / Marks K., Engel's F. Soch. 2-e izd. T. I. T. 23. S. 43-784. (In Russian).

Martynovskii S.V. (2008), Ekonomicheskaya politika: problemy dostizheniya tseli. Odessa: Pal'mira, 2008. 186 s. (In Russian).

Marshall A. (1993), Printsipy ekonomicheskoi nauki: v 3 t. Moskva: Progress: Univers, 1993. (In Russian).

Metodicheskie ukazaniya po spetskursu "Problemy tovarno-denezhnykh otnoshenii pri sotsializme" dlya studentov III kursa zaochnogo otdeleniya vsekh form obucheniya / Sost. K.V. Lykov. (1984), Odessa: OINKh, 1984. 32 s. (In Russian).

Nesenenko P.P., Artemenko O.A., Patlatoi O.Ye. (2019), Teoretichni osnovi ekonomichnoyi politiki: navchal'nii posibnik. Kyiv: FOP Gulya€va V.M., 2019. 306 s. (In Ukrainian).

Selishchev A.S., Selishchev N.A. (2004), Kitaiskaya ekonomika v XXI veke. Sankt-Peterburg: Piter, 2004. 240 s. (In Russian).

Si Tszin'pin. (2014), O gosudarstvennom upravlenii. Pekin: Izdatel'stvo literatury na inostrannykh yazykakh, 2014. 630 s. (In Russian).

Stalin I.V. (1952), Ekonomicheskie problemy sotsializma v SSSR. Moskva: Gospolitizdat. 96 s. (In Russian). 